Actualités scientifiques. By Max de Nansouty. Pp. 329. (Paris: Schleicher Frères et Cie., I904.) Price $3 \cdot 5^{\circ}$ francs.

THIs collection of short popular essays on scientific subjects is likely to appeal to a wide circle of readers. The questions selected for treatment are those pertaining to recent discoveries which have been given prominence in the Press. To name a few of the titles is enough to show the character of the book, especially when it is added that a subject is rarely given more than four pages by way of explanation:- Radium and radio-activity, wireless telegraphy, captive balloons, electric cookery, and so on. The book may prove of service in this country to young people fond of science who are learning French.

\section{LETTERS TO THE EDITUR.}

[The Editor does not hold himself responsible for opinions expressed by his correspondents. Neither can he undertake to return, or to correspond with the writers of, rejected manuscripis intended for this or any other part of NATURE No notice is taken of anonymous cimmumcations.]

\section{An Optical Phenomenon.}

A SHORT time ago, when experimenting with a cubical mirror, I noticed the following peculiar phenomenon :-

Diffused daylight from a near window fell on the mirror, and was reflected towards the observer. Now, the mirror was made to revolve slowly. A succession of flashes of white light was thrown at the observer as the different faces passed before the eye. When the rate of about two revolutions per second was reached, instead of the white flashes, a display of various colours, resembling interference colours, was observed, and this effect continued unti about six revolutions per second were made, when the colours disappeared, and a uniform grey light was reflected. The experiment was repeatedly made, and always with the same effect.

The exact moment of appearance and disappearance of the colour effect could only be determined approximately, nor is there, apparently, a definite order in which the colours succeed each other. At least, I was unable to distinguish a strict order, but this may have been due to the imperfect way of turning the mirror, viz., by hand power, means of obtaining an absolutely uniform rate not, being available. As a rule, several colours appear at the same time, one near the other. On the whole, however, it may be said that green tints predominate, whilst yellow hardly appears. Bluish tints seem to predominate at the beginning and towards the end of the colour range.

The experiment may also be varied in the following manner:--Place the mirror so that the direct sunlight strikes it. Then turning the mirror, observe the path of reflected light on the wall. In this path, not far from the mirror, fasten a piece of white paper to the wall. When the mirror is then turned at the above-named rate, the colours will be seen on the paper.

To secure a quick perception of the colours, it is well in both cases, to start with a high speed of rotation, and then to slacken it gradually.

I would like to know whether this phenomenon has already been observed by others, and also how it may be explained.

St. John's College, Toledø, Ohio, U.S.A.

\section{The Celtic Pony.}

At a sale of Icelandic and Welsh ponies held at Gateshead on July I4, I observed a small black Welsh stallion which had the essential characteristics of the Celtic pony (Equus caballus celticus) lately described by Prof. Ewart. There was no trace of a callosity on either hind leg, and the tail had a very well marked caudal fringe or tail-lock, while in most other respects this pony conformed to the Celtic type. I believe that this is the first instance on record of a Welsh pony resembling the Celtic variety in No. I 8 I6, VOL. 70] all the main points. The other Welsh ponies at the sale, so far as I noticed, possessed hock callosities, but the majority of these resembled the Celtic pony in having a more or less distinct caudal fringe.

The occurrence of "Celtic" characters in Welsh and other ponies which usually differ from $E$. caballus celticus, as pointed out by $\mathrm{Mr}$. Annandale and myself in a paper on Færöe and Icelandic ponies (Proc. Camb. Phil. Soc., vol. xii., 1904), is in no way inconsistent with the view we put forward that the present distribution of the Celtic pony is related to the Viking migration. This view receives confirmation in Dr. Stejneger's statement that there is a Norwegian breed called the "fjordhest" which is closely allied to if not identical with the Celtic pony. But though the purest representatives of the Celtic pony at the present day seem to be generally restricted to certain (usually isolated) parts of north-west Europe, it would appear that there are traces elsewhere of the primitive small-headed horse (the probable ancestor of the Celtic pony, according to Prof. Ewart) which had a wider distribution. The Welsh and other ponies which sometimes show Celtic characters, as well as certain of the smaller Arabs, probably represent such traces (see Ewart, "The Multiple Origin of Horses and Ponies," Trans. Highland and Agric. Society of Scotland, I904).

Out of sixty Icelandic ponies which I examined at the Gateshead sale, I found fourteen without hock callosities, a rather unusually high proportion. All colours were represented, but the commonest and probably the most typical colour with the Icelandic ponies was light dun with a dark line down the centre of the back.

Francis H. A. Marshall. Monksfield, Freshwater Bay, Isle of Wight, August ro.

\section{THE NEEDS OF ANTHROPOLOGY AT CAMBRIDGE.}

$A T$ first sight it does not strike one as a particularly edifying spectacle to see an appeal for funds made by a department of an ancient university, but after all it is a hopeful sign, as it indicates normal expansion or growth along new lines. It is a common mistake to regard the Universities of Oxford and Cambridge as well endowed; the wealth, such as it is - or rather such as it was-belongs to the colleges and not to the university, and as these universities are not endowed with public funds, they have to rely solely upon ancient and recent benefactions in addition to fees received from students. Consequently, when old subjects expand rapidly, or new subjects arise, there are insufficient funds to meet their needs; especially is this the case for scientific subjects, as, in addition to the lecturers, class-rooms, and books of the older subjects, these require demonstrators, laboratories, apparatus, and specimens. Museums, which are a necessity to many branches of science, are expensive institutions to erect, maintain, and increase. They are a relatively new feature in university education, and, though they are at present regarded by some with suspicion and by more with dismay, they are essential alike to teaching and research, and it is safe to predict that their value will become increasingly recognised. The chief reasons why museums are so generally misunderstood are because they are too small or too badly constructed to display their contents; they are understaffed and starved in funds for cases and additions, and, finally, they are not properly arranged. The last count is very largely dependent upon the previous conditions, for only those who have had experience can fully realise the impossibility of orderly and educative installation when every department of the museum is overcrowded and new specimens or collections are continually coming in. It is usually extremely difficult for a curator to keep pace with the new material in addition to the ordinary routine work of a museum, and as scarcely any museum has any- 